\title{
nature
}

\section{Don't mention the war...}

The United States could taint the ITER project to build a prototype magnetic-confinement fusion reactor if it exploits the selection of a site to settle diplomatic scores. But its European partners don't need to let that happen.

$\mathrm{S}$ pencer Abraham, the US energy secretary, seems to have a preference over which European nation — France or Spain should apply to host the proposed ITER fusion reactor. Not surprisingly, perhaps, given Spain's support for the Bush Administration's war on Iraq, and France's opposition, it is the Spanish bid that he has been talking up.

By the end of this year, the ITER partners are expected to make a decision on where to build the world's next magnetic-confinement fusion device, which would explore the behaviour of superheated hydrogen ions over long enough periods to infer how they might act in a fusion-based power plant. There are four proposed sites: one in Japan, two in Europe and one in Canada.

Most eyes are turned to the two parties whose money has sustained the project so far: Japan and the European Union (EU). Russia is a long-standing partner, but can't afford to offer a site, and certainly isn't planning to advise Europe and Japan on its preference. Canada has offered a site in Ontario, but although its selection would suit participating researchers in the neighbouring United States, US officials have never spoken out in favour of the Canadian site. They must realize that such a public statement of support, from a nation that has only just decided to rejoin the project and is planning to contribute no more than $10 \%$ of its US\$5-billion costs, would be inappropriate.

This helps to explain why Abraham's comments, made on a visit to Madrid earlier this month, are causing some disquiet. He came perilously close to expressing US support for the Spanish bid to host ITER (see page 211). This is liable to offend the French government, as Abraham well knows.

France is one of the strongest European supporters of magneticconfinement fusion research in general, and of ITER in particular. Its Atomic Energy Commission has the technical and managerial expertise to take a leading role in the project, so the French bid is a very serious contender. Spain, meanwhile, also has a solid bid, and can argue to that its relatively young democracy, and less-welldeveloped physics community, means that it has more to gain from hosting such a prestigious international project.

Abraham could remove the sour taste left by his comments in Madrid by stating unequivocally that the choice of a European site for ITER is a matter for the EU. This would prevent the project being sucked into the vortex of recrimination created by the current US administration's self-avowed intention to punish France for having the gall to oppose its invasion of Iraq.

But even if Abraham declines to make such a statement, the EU can defuse the issue. Earlier this week, ministers from its member states agreed that the EU must soon come down in favour of just one of the European sites. If the project's European partners can make a clear choice between its two bidders before the final site selection is made, Abraham's untimely intervention will be moot.

\section{Gene patents and the public good}

A race to claim patents on the SARS virus raises questions about the patent system's ability to cope with genomics.

$\mathrm{B}$ arely had the last nucleotide in the genetic code of the SARS coronavirus been read when the race to claim intellectual rights to the sequence began. And among those filing was the US Centers for Disease Control and Prevention (CDC) in Atlanta, Georgia, in what was essentially a pre-emptive strike (see page 214). CDC director Julie Gerberding told reporters last week that, in private hands, a patent on the viral sequence might delay the development and refinement of tests and treatments for the contagious pneumonia that has already killed several hundred people.

Gerberding's admission gives tacit acknowledgement to a growing concern among biomedical researchers that broad patents on genetic sequences may, in some cases, have a stifling effect on research and negative consequences for public health. Take the struggle over predictive testing for breast cancer based on the BRCA1 and BRCA2 genes. Since the Utah-based company Myriad Genomics won a European patent on the genes in 2001, the Curie Institute in Paris, with the backing of the French government, has been fighting for the right to continue testing women for the genes, which it can do for about a third of what Myriad charges. A similar situation exists in Canada, where several provincial governments have told their health authorities to continue testing in the hope of ultimately winning in court the right to do so.

Although the extent of the problem is hard to quantify, the calls for action are growing louder. Britain's Nuffield Council on Bioethics last year recommended that in future, patents on genetic sequences should be the exception rather than the rule. In Canada, a report issued by Ontario's provincial government, following its experience with $B R C A 1$ and $B R C A 2$, explored solutions such as a compulsory licensing scheme in which a public entity would determine who should have access to which gene patents, and even set licensing fees. The Canadian Biotechnology Advisory Committee is now set to move the proposal on to the ministerial level in the federal government.

In the United States, however, there currently seems to be little momentum for change. Last year, US Representative Lynn Rivers (Democrat, Michigan) sponsored a bill in Congress that would have allowed healthcare entities to perform genetic diagnostic tests without fear of patent-infringement lawsuits. It would also have guaranteed an exemption from patent restrictions for basic research. But Rivers has since lost her seat in the House and the legislation has little hope of revival.

There are no clear-cut answers. But when pre-emptive patenting is necessary to ensure that rapid solutions are found to an important health problem, something seems to be out of balance. Policy-makers should investigate what checks and balances are necessary to ensure that the patent system continues to do its job of stimulating innovation for the public good. 